\title{
Acquired Factor III Deficiency
}

National Cancer Institute

\section{Source}

National Cancer Institute. Acquired Factor III Deficiency. NCI Thesaurus. Code C131623.

An acquired coagulation disorder characterized by the partial or complete absence of tissue factor (factor III) activity in the blood. 